\title{
Cost reduction and quality enhancement in passion fruit seedlings using alternative substrate
}

\section{Redução de custo e aumento da qualidade de mudas de maracujá azedo usando substrato alternativo}

\author{
Luana Nascimento da Silva; Lucas Kennedy Silva Lima²; Filipe Silva Aguiar³; \\ Onildo Nunes de Jesus ${ }^{4 *}$
}

\section{Highlights}

23 substrate formulations were evaluated to grow Passiflora edulis seedlings.

The use of hydrogel enriched promotes a substantial increase in seedling quality.

The use of fine coal reduces the cost of substrate and increases its aeration.

\begin{abstract}
Obtaining vigorous, quality seedlings is a complex task because it involves multiple physical, chemical and biological factors, with the substrate being a fundamental of this process. Therefore, this study proposes to evaluate different formulations of substrate mixtures and identify which provides better emergence vigor and shoot and root growth in passion fruit (Passiflora edulis Sims). The experiment was laid out in a completely randomized design consisting of 23 substrates with different proportions of Vivatto ${ }^{\circledR}$ and Osmocote ${ }^{\circledR}$, washed sand, soil, fine coal, coarse coal, enriched hydrogel and enriched vermiculite, with and without the addition of NPK, which were distributed into four replications of four plants per plot. To enrich the hydrogel and vermiculite, foliar fertilizer was used. Emergence vigor was evaluated throughout the seedling emergence period and seedling growth parameters were observed at 60 days after sowing. The data were subjected to multivariate analysis and the groups formed were subjected to analysis of variance. Based on principal component analysis (PCA), four groups were identified. The group composed only of soil + coarse coal and enriched hydrogel (2:2:1) was considered the best treatment, as it favored most of the vegetative growth and emergence vigor traits. Soil plus sand with the addition of NPK was not recommended to grow passion fruit seedlings in any of the proportions used, as there was no emergence.
\end{abstract}

Key words: Conventional substrate. Growth. Hydrogel. Multivariate analysis. Passiflora edulis Sims.

1 Student of the Agronomic Engineering Course at the Federal University of Recôncavo da Bahia, UFRB, Cruz das Almas, BA, Brazil. E-mail: luahnascimento@outlook.com

2 Jr. Post-Doctorate/CNPq. With research conducted at Embrapa Mandioca e Fruticultura, EMBRAPA, Cruz das Almas, BA, Brazil. E-mail: lucas18kennedy@gmail.com

3 Agronomist from the Federal University of Recôncavo da Bahia, UFRB, Cruz das Almas, BA, Brazil. E-mail: felipeaguiiiar@ hotmail.com

${ }^{4}$ Researcher at Embrapa Cassava and Fruit, EMBRAPA, Cruz das Almas, BA, Brazil. E-mail: onildo.nunes@embrapa.br

* Author for correspondence

Received: Sept. 30, 2020 - Approved: Nov. 09, 2020 


\section{Resumo}

A obtenção de mudas com qualidade e vigor é complexa, pois envolve múltiplos fatores físicos, químicos e biológicos sendo o substrato fundamental neste processo, assim, o objetivo deste trabalho foi avaliar diferentes formulações de substrato e identificar qual proporciona melhor vigor de emergnência e crescimento de parte aérea e raízes de maracujá amarelo (Passiflora edulis Sims). O delineamento experimental foi inteiramente casualizado, composto por 23 substratos, em diferentes misturas de Vivatto $^{\circledR}$, Osmocote ${ }^{\circledR}$, areia lavada, solo, resíduo de carvão fino, carvão grosso, hidrogel enriquecido e vermiculita enriquecida com adubo foliar, além de tratamentos com e sem adição de NPK, distribuídos em quatro repetições de quatro plantas por parcela. O vigor de emergência foi avaliado durante o período de emergência das plântulas e os parâmetros de crescimento das plântulas foram observados aos 60 dias após a semeadura. Os dados foram submetidos à análise multivariada e os grupos formados foram submetidos à análise de variância. Com base na análise de componentes principais (PCA), quatro grupos foram identificados. O grupo composto apenas de solo + carvão vegetal e hidrogel enriquecido (2:2:1), foi considerado o melhor tratamento, pois favoreceu a maioria das características de crescimento vegetativo e vigor de emergência. O solo mais a areia com a adição de NPK não foi recomendado para a produção de mudas de maracujá azedo em nenhuma das proporções utilizadas, pois não houve emergência.

Palavras-chave: Análise multivariada. Crescimento. Hidrogel. Passiflora edulis Sims. Substrato convencional.

\section{Introduction}

Yellow passion fruit (Passiflora edulis Sims) is the most widely produced and consumed species of the genus Passiflora in Brazil, with a yield of 602,651 metric tons from an area of 42,731 ha. Bahia stands out as the main producing state, accounting for $26.69 \%$ of the national production (Instituto Brasileiro de Geografia e Estatística [IBGE], 2020). It is widely accepted among Brazilian growers and consumers due to the organoleptic quality of its fruits, which are rich in minerals, vitamins $A$ and $C$ and antioxidants (Zeraik, Yariwake, Wauters, Tits, \& Angenot, 2012; Bomtempo, Costa, Lima, Engeseth, \& Gloria, 2016). The fruit crop is grown mainly by small farmers, with production areas ranging from 3 to 5 ha (Meletti, 2011).

Despite the importance of this crop in generating employment and income in several regions of Brazil, its yield is low, at $14.1 \mathrm{t} \mathrm{ha}^{-1}$ (IBGE, 2020), as compared with the production potential of the crop, which can exceed $40 \mathrm{t}$ ha-1 (Freitas, Oliveira, Cruz, \& Santos, 2011). One of the main limitations of the crop is the low level of technology adopted even in the production of seedlings (Faleiro et al., 2019), sometimes involving poor substrates in the physical and chemical aspects. For planting, it is recommended to use healthy, vigorous seedlings free from attack by pests and diseases (Farias et al., 2019). In this respect, the use of a good substrate is fundamental to achieve the maximum vigor of the plant, allowing earlier planting and higher economic return for farmers.

The adoption of technical standards for the composition of substrates can improve the quality of the seedlings produced, resulting in plants that are more uniform, vigorous and resistant to environmental adversities after 
planting (Caldeira, Peroni, Gomes, Delarmina, \& Trazzi, 2012). A substrate considered suitable to produce seedlings must provide good conditions for moisture retention, an adequate ratio between macro- and microporosity and absence of pathogens and spontaneous-plant seeds (Rocha, Silva, Saraiva, \& Dayrell, 2017). However, in addition to good physical and phytosanitary traits, nutrient availability is one of the main factors influencing the suitability of substrates for plant growth (Ludwig Fernandes, Guerrero, \& Bôas, 2014). Regarding mineral fertilization, the correct inclusion of certain nutrients is essential for their balanced uptake, so as not to cause toxicity or deficiency (Aular \& Natale, 2013; Alencar et al., 2016).

In addition to physical and chemical quality, the materials used in substrate formulations must be reasonably priced to reduce production costs. Several studies have been carried out with the genus Passiflora in which substrates with the addition of NPK (Miyake, Creste, Narita, \& Guerra, 2017) organic substrates (Lima et al., 2016) and mining wastes (Silva, Brito, Brito, Mesquita, \& Silva, 2016) were tested. However, these studies have shown varied results regarding the formulation and time needed to obtain seedlings, without jointly favoring chemical and physical traits of the substrate, falling short of the desired potential for seedling production. The physical properties of the substrate are as important as the chemical attributes. In this sense, interesting results were described in recent studies with Pará rubber tree (Hevea brasiliensis) (Lira, Souza, \& Maia, 2019) and earpod tree (Enterolobium contortisiliquum (Vell.) Morong) (Silva et al., 2019) using hydrogel in the formulation of the substrate. Nonetheless, there is no report of this type for the production of $\mathrm{P}$. edulis seedlings.
Coal waste is a byproduct rich in $\mathrm{Ca}, \mathrm{Mg}$, organic matter and carbon after the selection of the charcoal for sale. About 597 million tons of biomass waste is produced each year in Brazil. Thus, the use of this byproduct in the formulation of substrate could contribute to the recycling of waste and carbon storage in the soil, in addition to reducing the costs of producing seedlings (Novotny, Maia, Carvalho, \& Madari, 2015) as well as offering a suitable use for this byproduct (Freitas, Souza, Cardoso, \& Paiva, 2014).

The substrates used in this study with coal waste and enriched hydrogel can possibly reduce costs and improve the characteristics of the substrate and thus enhance seedling development. Moreover, the adequate proportion and composition to meet the nutritional requirements of passion fruit seedlings are still unknown. In this scenario, this study was conducted to examine the effect of different substrates and to identify which provides better vigor emergence and shoot and root growth in Passiflora edulis.

\section{Material and Methods}

The experiment was conducted in an area covered by anti-aphid screening in the premises of the Embrapa Cassava and Fruits research unit (Embrapa Mandioca e Fruticultura), located in Cruz das Almas, Bahia, Brazil (12³9'25" S, 3907'27" W, 222 m asl).

Seeds of Passiflora edulis Sims (BGP418) from the Passiflora Germplasm Bank of Embrapa were used. The seeds were extracted from ripe fruits obtained from controlled pollination, washed in running water and dried at room temperature for one week until their use in the test. The experiment was 
laid out in a completely randomized design, consisting of 23 treatments (Table 1) that were distributed into four replications of four plants per plot.

The substrates were formulated from a mixture of different materials (Vivatto ${ }^{\circledR}$, washed sand, soil, fine coal waste $(\leq 3.0 \mathrm{~mm})$, coarse coal waste (3.0 to $10.0 \mathrm{~mm}$ ), hydrogel and vermiculite). The hydrogel was enriched with nutrient solution, which was prepared by diluting $10 \mathrm{~g}$ of the soluble foliar fertilizer Forth ${ }^{\circledR}$ in $1.0 \mathrm{~L}$ of water $\left(10 \mathrm{~g} \mathrm{~L}^{-1}\right)$ using $1.0 \mathrm{~L}$ of the nutrient solution to $5.0 \mathrm{~g}$ of hydrogel. To prepare the enriched vermiculite, the same nutrient solution was used at a 1:1 (v:v) ratio (vermiculite:nutrient solution). In the Vivatto ${ }^{\circledR}$ + fiber + Osmocote ${ }^{\circledR}$, control, 1:1:1 and control + fine coal + enriched hydrogel treatments, the Osmocote $^{\circledR}$ slow-release fertilizer (300 $\mathrm{g}$ for each $5.0 \mathrm{~L}$ of substrate) was used. In the treatments with NPK addition, urea $(45 \%$
$\mathrm{N})$, single superphosphate $\left(18 \% \quad \mathrm{P}_{2} \mathrm{O}_{5}\right)$ and potassium chloride $\left(60 \% \mathrm{~K}_{2} \mathrm{O}\right)$ were used in the amounts of $1.0 \mathrm{~g} \mathrm{~N}, 0.3 \mathrm{~g} \mathrm{P}_{2} \mathrm{O}_{5}$ and 0.11 $\mathrm{g} \mathrm{K}_{2} \mathrm{O}$ (Table 1). Some of the treatments that received NPK (soil + fine coal + NPK 4:1; soil + coarse coal + NPK 4:1; soil + sand + NPK 4:1; soil + sand + NPK 3:2; soil + sand + NPK 2:3; soil + fine coal + enriched vermiculite $3: 1: 1$; and soil + coarse coal + enriched vermiculite + NPK 3:1:1) were eliminated from the statistical analysis, since there was no seedling emergence in these substrates. As a control treatment, a mixture formed by commercial substrates commonly used in the production of passion fruit seedlings was used (Table 1). After formulation, the substrates (except SFcNPK4:1, SCcNPK4:1, SSNPK4:1, SSNPK3:2, SSNPK2:3, SFcEvNPK3:1:1 and SCcEvNPK3:1:1) were analyzed to determine the chemical composition (Table 2). 
Table 1

Proportion of substrates and standard concentration of NPK used to produce seedlings of Passiflora edulis Sims

\begin{tabular}{|c|c|c|c|c|c|c|}
\hline Treatment $^{1}$ & Substrate & $\begin{array}{l}\text { Proportion } \\
\text { (v:v) }\end{array}$ & $\begin{array}{c}\text { NPK } \\
\text { (g/plant) }\end{array}$ & $\begin{array}{l}\text { Density } \\
\left(\mathrm{kg} / \mathrm{m}^{3}\right)\end{array}$ & $\begin{array}{c}\text { Cost } \\
\left(\mathrm{US} \$ / \mathrm{m}^{3}\right)\end{array}$ & $\begin{array}{l}\text { Cost } \\
(\%)\end{array}$ \\
\hline SFcNPK4:1 & & $4: 1$ & $1: 0.3: 0.11$ & 867 & 4.33 & 0.33 \\
\hline SFcNPK3:2 & Soil + Fine coal & $3: 2$ & 1:0.3:0.11 & 709 & 3.26 & 0.25 \\
\hline SFCNPK2:3 & & $2: 3$ & 1:0.3:0.11 & 710 & 2.20 & 0.17 \\
\hline SCcNPK4:1 & & $4: 1$ & 1:0.3:0.11 & 848 & 4.33 & 0.33 \\
\hline SCcNPK3:2 & Soil + Coarse coal & $3: 2$ & 1:0.3:0.11 & 646 & 3.26 & 0.25 \\
\hline SCcNPK2:3 & & $2: 3$ & 1:0.3:0.11 & 676 & 2.20 & 0.17 \\
\hline SSNPK4:1 & & $4: 1$ & 1:0.3:0.11 & 2100 & 5.96 & 0.45 \\
\hline SSNPK3:2 & Soil + Sand & $3: 2$ & 1:0.3:0.11 & 1460 & 6.53 & 0.50 \\
\hline SSNPK2:3 & & $2: 3$ & 1:0.3:0.11 & 2180 & 7.10 & 0.54 \\
\hline SFcEvNPK3:1:1 & Soil + Fine coal + Enriched & $3: 1: 1$ & 1:0.3:0.11 & 1525 & 75.29 & 5.76 \\
\hline SFcEvNPK2:2:1 & vermiculite & $2: 2: 1$ & 1:0.3:0.11 & 1200 & 74.23 & 5.67 \\
\hline SFcEv3:1:1 & Soil + Fine coal + Enriched & $3: 1: 1$ & --- & 716 & 75.29 & 5.76 \\
\hline SFcEv2:2:1 & vermiculite & $2: 2: 1$ & --- & 588 & 74.23 & 5.67 \\
\hline SCcEvNPK3:1:1 & Soil + Coarse coal + Enriched & 3:1:1 & 1:0.3:0.11 & 654 & 75.29 & 5.76 \\
\hline SCcEvNPK2:2:1 & vermiculite & $2: 2: 1$ & 1:0.3:0.11 & 661 & 74.23 & 5.67 \\
\hline SCcEv3:1:1 & Soil + Coarse coal + Enriched & 3:1:1 & --- & 744 & 75.29 & 5.76 \\
\hline SCcEv2:2:1 & vermiculite & $2: 2: 1$ & --- & 674 & 74.23 & 5.67 \\
\hline SFcEh3:1:1 & Soil + Fine coal + Enriched & $3: 1: 1$ & --- & 332 & 34.29 & 2.62 \\
\hline SFcEh2:2:1 & hydrogel & $2: 2: 1$ & --- & 762 & 33.23 & 2.54 \\
\hline SCcEh3:1:1 & Soil + Coarse coal + Enriched & 3:1:1 & --- & 760 & 34.29 & 2.62 \\
\hline SCcEh2:2:1 & hydrogel & $2: 2: 1$ & --- & 768 & 33.23 & 2.54 \\
\hline VFO1:1 & $\begin{array}{l}\text { Vivatto }^{\circledR}+\text { Fiber + Osmocote }^{\circledR} \\
\text { (Control) }\end{array}$ & 1:1:1 & --- & 301 & 343.43 & 26.26 \\
\hline CFcEh2:2:1 & $\begin{array}{l}\text { Control + Fine coal + Enriched } \\
\text { hydrogel }\end{array}$ & $2: 2: 1$ & --- & 412 & 191.63 & 14.65 \\
\hline
\end{tabular}

${ }^{1}$ Because the cost of Vivatto ${ }^{\circledR}$, Hydrogel and Osmocote ${ }^{\circledR}$ takes into account the price of the product sold (includes fees, labor, processing, etc.), the price is higher. 
¿

m

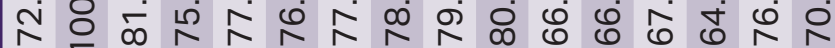

岕

离

ष

$\stackrel{+}{ \pm}$

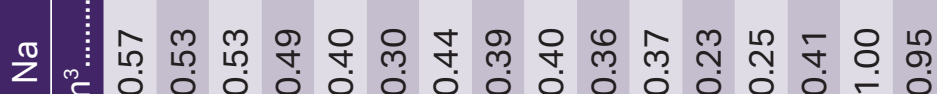

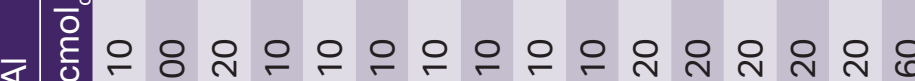

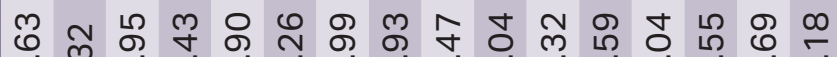
ט่

ㄱำ г

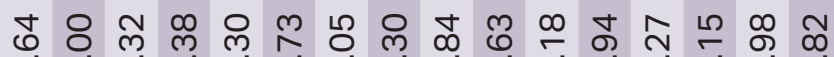
+

○े

$\stackrel{0}{\Sigma}$

융

ঠัర

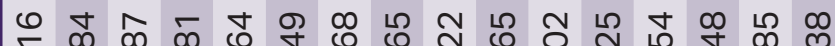

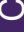

$x$ ᄂ $\therefore$ r

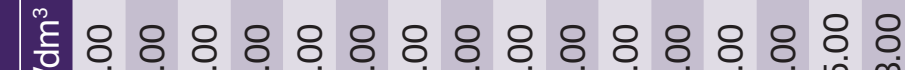

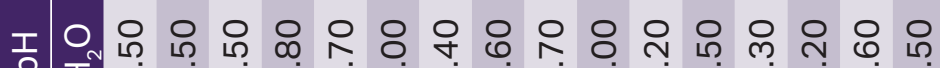

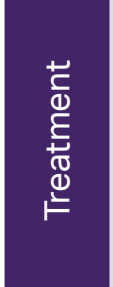

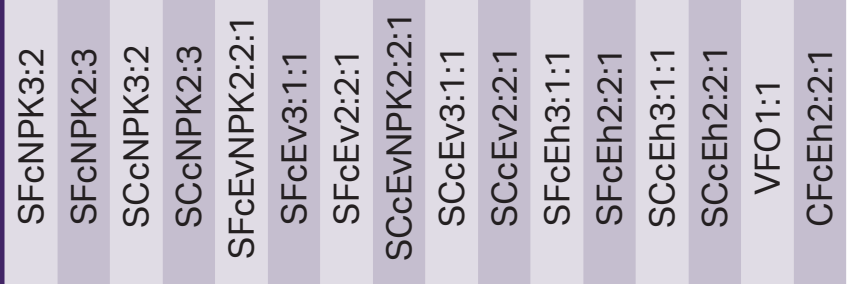

$\overline{\overline{0}}$

"11

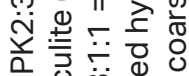

之.

U 단 Q तิ लु

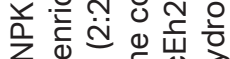
$++\frac{1}{5}$ U $\frac{1}{\pi} \frac{+}{\pi} \frac{1}{2}+\infty \frac{0}{0}$ O $0+\overline{0}$ ڤ) $\overline{0}+.0 \%$

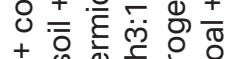

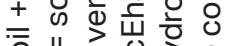
i II 엉 "Iष्ट

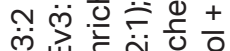

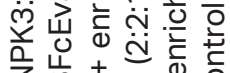
$\sum_{0} \begin{aligned} & 0+\frac{d}{\omega} \\ & 0\end{aligned}$

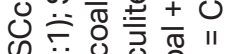

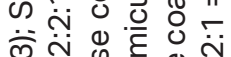

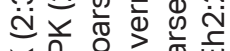

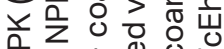
$\bar{z}+ \pm 0.4$

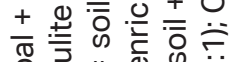
에 1100

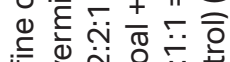

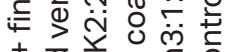
$+\overline{\overline{0}}$ क 仓 崩 II 岂 更 ฟิن $+\infty$ 足

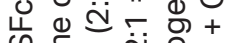
心 은

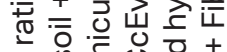
ํ. की ह ले II

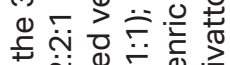

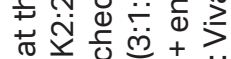
준 之交品 + 嵌 +.0.

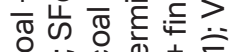
ठ

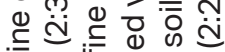
$+\frac{1}{+}+\frac{\overline{0}}{0}$

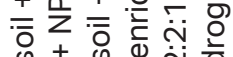
॥ त $\|+$ 虫 잉 - 뜽 نे

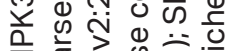

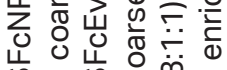


The substrates were mixed and kept at rest for ten days and later distributed into polyethylene tubes with dimensions of $12.0 \mathrm{x}$ $1.4 \mathrm{~cm}$ and $280 \mathrm{~cm}^{3}$. The seeds were sown at a depth of $1.0 \mathrm{~cm}$ and irrigated daily. To calculate the cost of the substrates, the average prices of the materials used to compose them were quoted at a farm supply store and on the Internet, based on the prices charged in November 2019, and the costs to produce 1.0 $\mathrm{m}^{3}$ of substrate were estimated. The resulting monetary values were later converted from Brazilian currency $(\mathrm{R} \$$ ) into US dollars using the exchange rate of $\mathrm{R} \$ 5.27=$ US\$ 1 (Table 1).

The evaluated variables were emergence speed index (ESI), where the number of seedlings emerged was counted every two days starting at 15 days after sowing (DAS) $\left(E S I=E_{1} / N_{1}+E_{2} / N_{2}+\ldots E_{n} / N_{n}\right.$ [where $E_{1}$ $E_{2} \ldots E n=$ number of seedlings found in the first, second and last counts; and $N_{1}, N_{2} \ldots N_{n}$ = number of DAS in the first, second and last counts]); emergence percentage at 60 DAS; and average emergence time. The seedlings considered as emerged were those that showed free and normal cotyledons (Maguire, 1962).

The biometric variables evaluated at 60 DAS were plant height $(\mathrm{PH}$, in $\mathrm{cm})$, measured with a ruler; number of leaves (NL); stem diameter ( $S D$, in $\mathrm{mm})$, measured with a caliper at $3.0 \mathrm{~cm}$ from the neck of the plant; leaf area $\left(L A\right.$, in $\left.\mathrm{cm}^{2}\right)$, where the leaves were distributed on a white surface with a millimeter rule that served as a reference to estimate the leaf area using Image $J^{\circledR}$ software; and total chlorophyll content, determined using a chlorophyll meter (CCM-200 chlorophyll content meter, Opt Sciences ${ }^{\circledR}$.
Roots were placed in $30 \%$ alcohol and refrigerated and then subjected to image scanning analysis to evaluate the following traits: total root length ( $T R L$, in $\mathrm{cm}$ ); average root diameter (ARD, in $\mathrm{mm}$ ); total root volume $\left(\mathrm{RV}\right.$, in $\left.\mathrm{cm}^{3}\right)$; and total root length as a function of the following root diameter classes: RL 1: 0.0 to $\leq 0.5 \mathrm{~mm}$; RL2: $>0.5 \leq 1.0 \mathrm{~mm}$; RL3: $>1.0 \leq 1.5$ $\mathrm{mm} ; \mathrm{RL} 4:>1.5 \leq 2.0 \mathrm{~mm}$; RL5: > $2.0 \leq 2.5 \mathrm{~mm}$; and RL6: > $2.5 \mathrm{~mm}$ diameter. Image processing was performed using WinRizho software version 2013d, at 400 dpi resolution. Shoot dry weight (SDW) and root dry weight (RDW) were obtained after drying in a forced-air oven at 65 ${ }^{\circ} \mathrm{C}$ until reaching constant weight.

The data were transformed $(\mu /$ standard deviation) to normalize the rating scale of the different traits and subsequently subjected to multivariate analysis using the Euclidean distance as a measure of dissimilarity and the UPGMA method (unweighted pair group method with arithmetic mean). In addition, the data were subjected to principal component analysis (PCA) and the treatments were plotted in relation to the two principal components (PC1 and PC2), which explained most of the variability of the emergence and growth data, and with the root data to observe which traits contributed the most to group discrimination. The analyses were performed using the prcomp procedure in R software v. 3.5 (R Development Core Team [R], 2018).

The number of groups was defined based on cluster analysis and distribution into $\mathrm{PC}_{1}$ and $\mathrm{PC}_{2}$. From the groups, the box plots for each trait were generated and the data were subjected to analysis of variance. When significant, means were compared by Tukey's test $(p \leq 0.05)$. 


\section{Results and Discussion}

The first two components explained $85.7 \%$ of the variability of the shoot and emergence vigor data (Figure 1a). In PC1, the factors with the greatest contribution were height (14.7\%) and number of leaves (14.3\%). In PC2, total chlorophyll content and emergence percentage had the greatest weight in its constitution, with 23.2 and $22.7 \%$, respectively (Figure 1a).
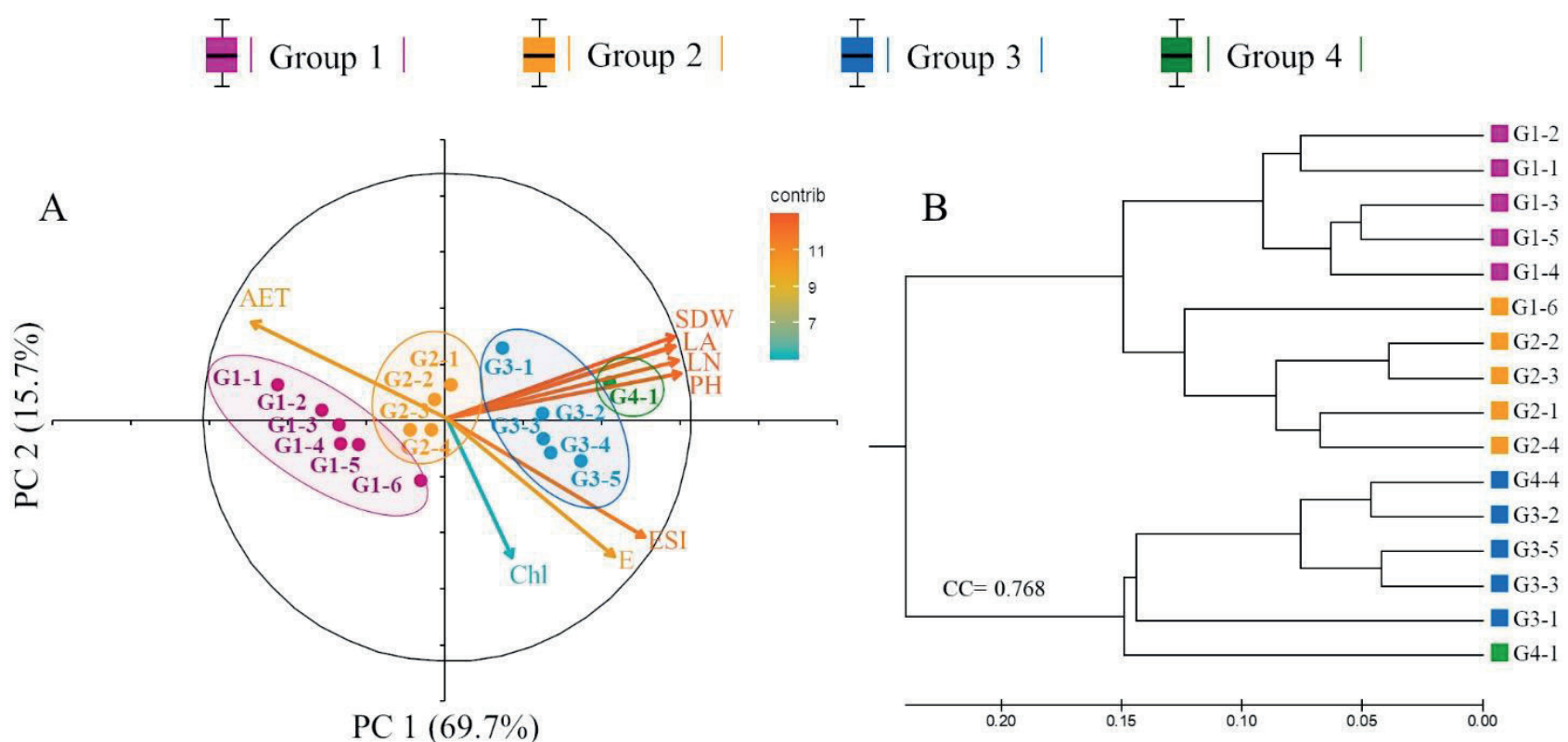

Figure 1. Emergence vigor and shoot traits in Passiflora edulis plants subjected to treatments with different substrates evaluated at 60 days after sowing and emergence speed index (ESI, evaluated during the emergence period). A: principal component analysis for the emergence vigor and shoot variables; B: dendrogram referring to the clusters according to the emergence vigor and shoot variables. The arrows represent the direction of the trait and its gradient colors represent the contribution of each trait to the components, from the blue gradient (low contribution) to red (high). AET: average emergence time; Chl: total chlorophyll; E: emergence; ESI: emergence speed index; PH: plant height; NL: number of leaves; LA: leaf area; SDW: shoot dry weight. G1-1: SCcNPK3:2 = soil + coarse coal + NPK at the 3:2 ratio; G1-2: SFcNPK 2:3 = soil + fine coal + NPK (2:3); G1-3: SCcNPK2:3 = soil + coarse coal + NPK (2:3); G1-4: SFcEvNPK 2:2:1 = soil + fine coal + enriched vermiculite + NPK (2:2:1); G1-5: SCcEvNPK2:2:1 = soil + coarse coal + enriched vermiculite + NPK (2:2:1); G1-6: SFcNPK2:3 = soil + fine coal + NPK (2:3); G2-1: SCcEv3:1:1 = soil + coarse coal + enriched vermiculite (3:1:1); G2-2: SFcEv3:1:1 = soil + fine coal + enriched vermiculite (3:1:1); G2-3: SFcEv2:2:1 = soil + fine coal + enriched vermiculite (2:2:1); G2-4: VFO 1:1: Vivatto + fiber + Osmocote ${ }^{\circledR}$ (Control) (1:1); G3-1: CFcEh2:2:1 = Control + fine coal + enriched hydrogel (2:2:1); G32: SCcEv 2:2:1 = soil + coarse coal + enriched vermiculite (2:2:1); G3-3: SFcEh2:2:1 = soil + fine coal + enriched hydrogel (2:2:1); G3-4: SCcEh3:1:1 = soil + coarse coal + enriched hydrogel (3:1:1); G3-5: SFcEh3:1:1 = soil + fine coal + enriched hydrogel (3:1:1); G4-1: SCcEh2:2:1 = soil + coarse coal + enriched hydrogel (2:2:1). 
The distribution of the 23 substrates used in this study for shoot and emergence data resulted in the formation of four groups, with the soil + coarse coal + enriched hydrogel (2:2:1) treatment being the substrate that most stood out. This treatment formed a separate group, with a direct influence of the following shoot traits: SDW, PH, LA and NL (Figure 1a).

A larger leaf area is related to increased photosynthetic activity (Almeida, Cruz, Castro, \& Fagundes, 2014), which translates into a greater increase in dry weight. This result demonstrates that this substrate had adequate physical and chemical traits, which positively influenced the weight, height and number of leaves, corroborating the importance of substrate quality in seedling production (W. L. Silva et al., 2016). In addition, this treatment had a low percentage cost $(2.54 \%)$ as compared with the control treatment, which represented $26.26 \%$ of the total cost (Table 1). The second best group (blue), composed of five substrates, contained vermiculite or hydrogel enriched with foliar fertilizer (Figure 1a). It is important to highlight that, unlike the other treatments, the cost of control treatment is overestimated, since it also includes other costs related to the production stages, on a commercial scale.

The substrates composed of soil + fine coal 3:2 (SFcNPK3:2, SFcNPK2:3), soil + coarse coal 3:2 (SCcNPK3:2, SCcNPK2:3), with the addition of NPK and with the addition of enriched vermiculite (SFcEvNPK 2:2:1, SCcEvNPK), formed the worst group according to the dendrogram, with lower performance in seedling quality and a strong influence of average emergence time (Figure 1a, b). Lower emergence percentages and emergence speed indexes resulted in lower seedling quality (Figure 1a), since the vigor parameters of $\mathrm{PH}, \mathrm{LA}, \mathrm{NL}$ and SDW did not correlate with these treatments.

Compaction increases penetration resistance (Ohland et al., 2014) and can interfere with germination and emergence. Thus, the low performance of these substrates in favoring the traits related to germination vigor may be directly related to the compaction of the substrate, which delayed the time needed for emergence of the radicle and production of cotyledons. This was corroborated by the fact that the average density of the substrates in group 1 were greater than in groups 2 and 3 (Table 1).

The enriched-hydrogel treatments were allocated to the best groups, with a result superior to the control, which exhibited an intermediate result (group 3) (Figure 1a). Hydrogel allows water to be retained and released gradually to the plant (Felippe et al., 2020), and its use has been widespread in other crops, such as papaya (Carica papaya L.) (Nomura, Pereira, Costa, Pereira, \& Ventura, 2019) and rubber (Hevea brasiliensis L.) (Lira et al., 2019). However, for the initial establishment of plants in the field, studies aimed at their enrichment with nutrient solutions are scarce in the literature.

Principal component analysis performed on the root traits followed the same trend as the results observed for shoot and emergence data, with emphasis on the treatment using hydrogel enriched with foliar fertilizer. The root attributes resulted in the formation of more homogeneous groups (Figure 2a).

The variability of the data was explained by $80.8 \%$ in $\mathrm{PC} 1$ and $9.9 \%$ in $\mathrm{PC} 2$, which totaled $90.7 \%$ of the total variability. In PC1, 
the variables that most influenced the growth of $P$. edulis seedlings were root volume (12.1\%) and total root length (12.0\%), while PC2 was influenced by average root diameter (53.1\%) and the last root class with diameter greater than $2 \mathrm{~mm}$ (Figure 2a).

Average root diameter was negatively correlated with the other root variables, meaning that the substrates that favored important traits such as root length and volume also favored the development of roots with smaller average diameters. The substrates of group 1, enriched with NPK, favored the development of roots with larger diameters (Figure 2a; Figure 3n).
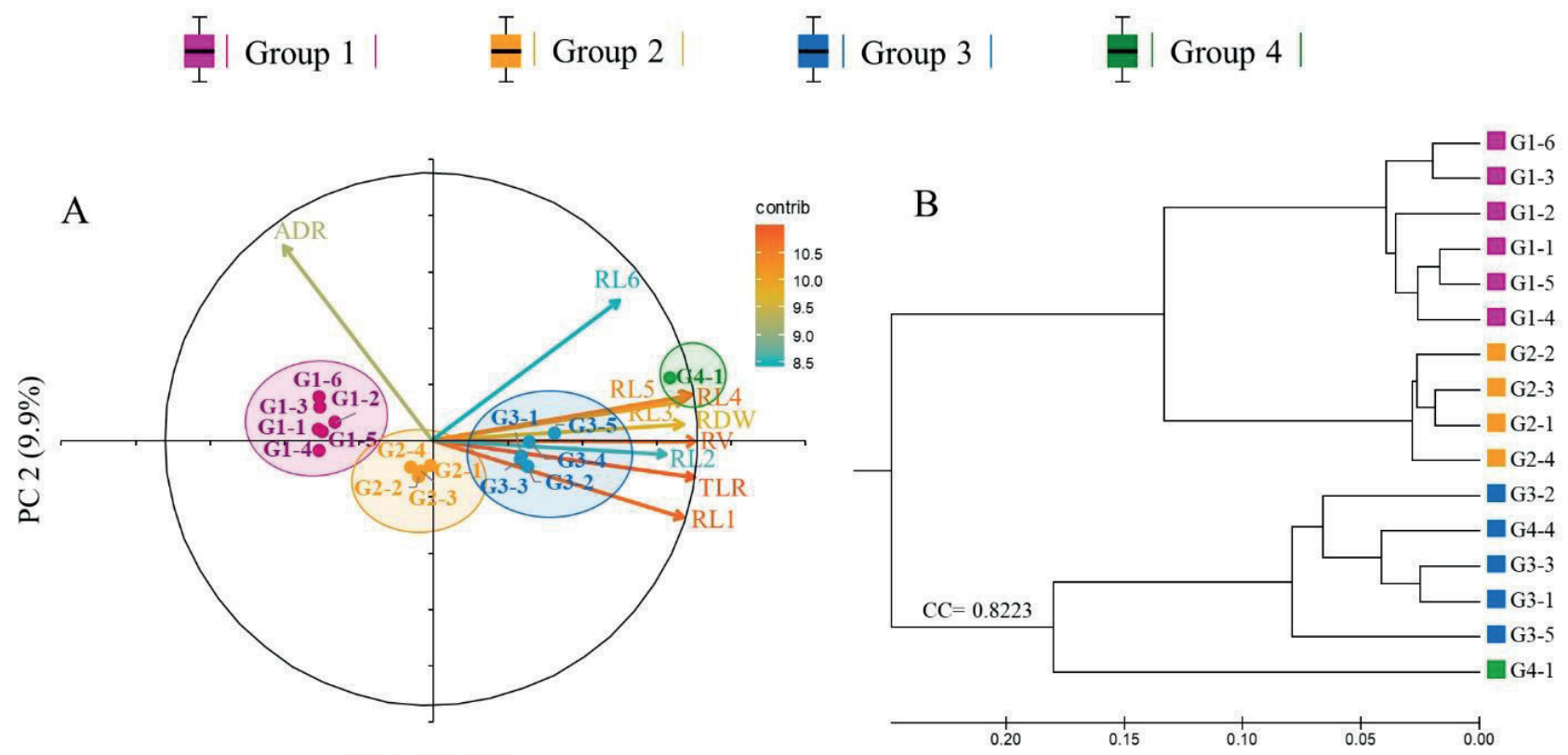

PC $1(80.8 \%)$

Figure 2. Root traits of Passiflora edulis plants subjected to treatments with different substrates evaluated at 60 days after sowing. A) principal component analysis (PCA) for the root variables; $B)$ dendrogram referring to the groupings according to the root variables. The arrows represent the direction of the trait and the gradient colors represent the contribution of each traits to the components, from the blue gradient (low contribution) to red (high). ADR: average root diameter; RDW: root dry weight; TRL: total root length; RV: total root volume; root length as a function of root diameter classes RL1: 0.0 to $\leq 0.5 \mathrm{~mm}$; RL2: > $0.5 \leq 1.0 \mathrm{~mm}$; RL3: > $1.0 \leq 1.5 \mathrm{~mm}$; RL4: $>1.5 \leq 2.0$ $\mathrm{mm}$; RL5: > $2.0 \leq 2.5 \mathrm{~mm}$ and RL6: > $2.5 \mathrm{~mm}$ diameter. G1-1: SCcNPK3:2 = soil + coarse coal + NPK at the 3:2 ratio; G1-2: SFcNPK 2:3 = soil + fine coal + NPK (2:3); G1-3: SCcNPK2:3 = soil + coarse coal + NPK 2:3; G1-4: SFcEvNPK 2:2:1 = soil + fine coal + enriched vermiculite + NPK (2:2:1); G1-5: SCcEvNPK2:2:1 = soil + coarse coal + enriched vermiculite + NPK (2:2:1); G1-6: SFcNPK2:3 = soil + fine coal + NPK (2:3); G2-1: SCcEv3:1:1 = soil + coarse coal + enriched vermiculite (3:1:1); G22: SFcEv3:1:1 = soil + fine coal + enriched vermiculite (3:1:1); G2-3: SFcEv2:2:1 = soil + fine coal + enriched vermiculite (2:2:1); G2-4: VFO1:1: Vivatto ${ }^{\circledR}+$ fiber + Osmocote ${ }^{\circledR}$ (Control) (1:1); G3-1: CFcEh2:2:1 = Control + fine coal + enriched hydrogel (2:2:1); G3-2: SCcEv2:2:1 = soil + coarse coal + enriched vermiculite 2:2:1); G3-3: SFcEh2:2:1 = soil + fine coal + enriched hydrogel (2:2:1); G3-4: SCcEh3:1:1 = soil + coarse coal + enriched hydrogel (3:1:1); G3-5: SFcEh3:1:1 = soil + fine coal + enriched hydrogel (3:1:1); G4-1: SCcEh2:2:1 = soil + coarse coal + enriched hydrogel (2:2:1). 
The increase in root length is associated with the formation of thinner roots, and when there are limitations on root development due to the presence of chemical or physical impediments, the exploration of the soil surface by roots is restricted to the uppermost layers, where they tend to have larger diameters (Mazurana et al., 2013). In this respect, it is likely that the excess NPK caused toxicity to the root system of the seedlings, resulting in an expansion of the cortex parenchyma cells. When compared with control, the treatments of groups 4 and 3 corresponded to the substrates that offered more favorable conditions for the development of the seedlings, producing thinner roots. These absorb more water and nutrients, favoring plant development (Comas, Becker, Cruz, Byrne, \& Dierig, 2013).

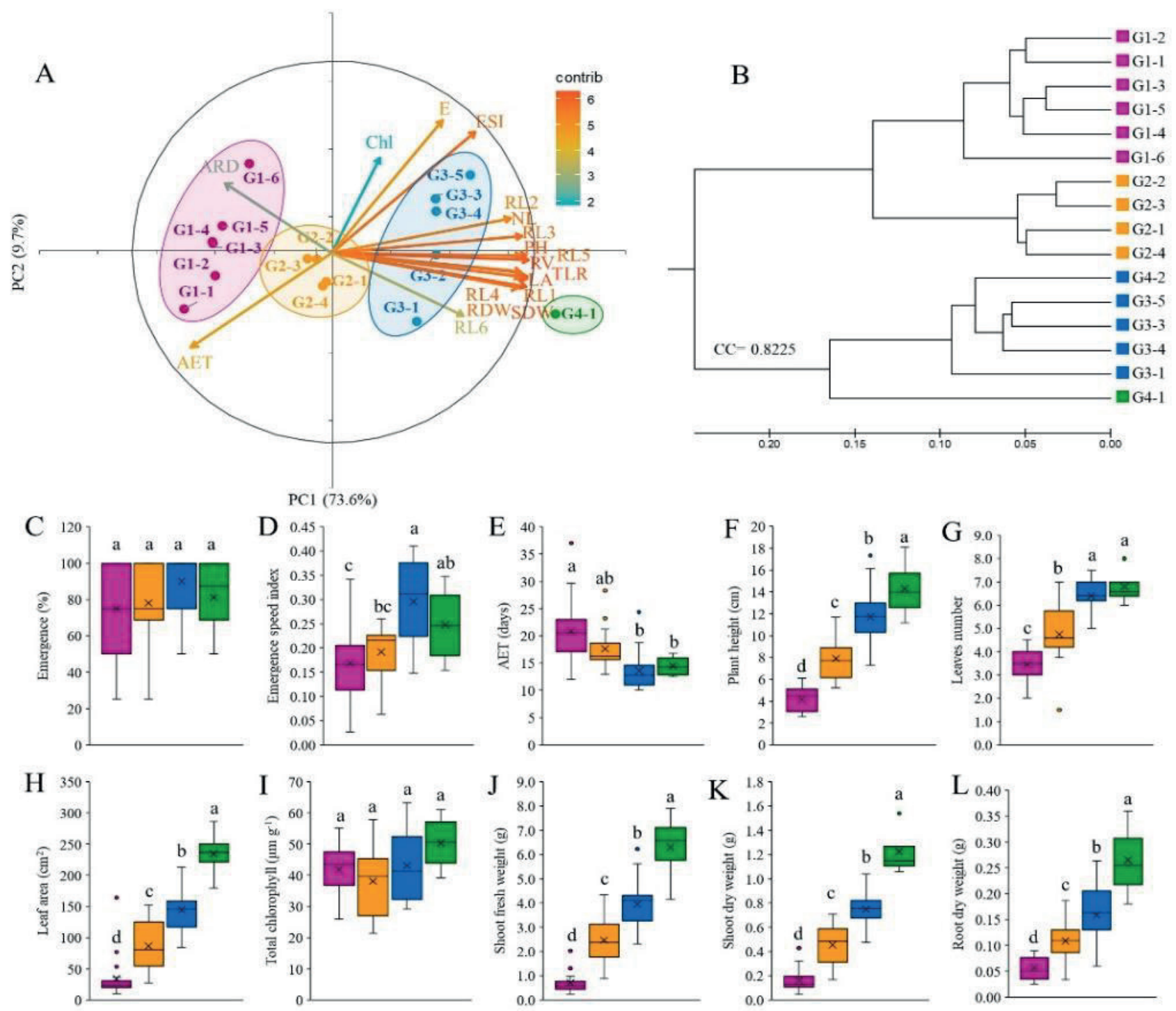



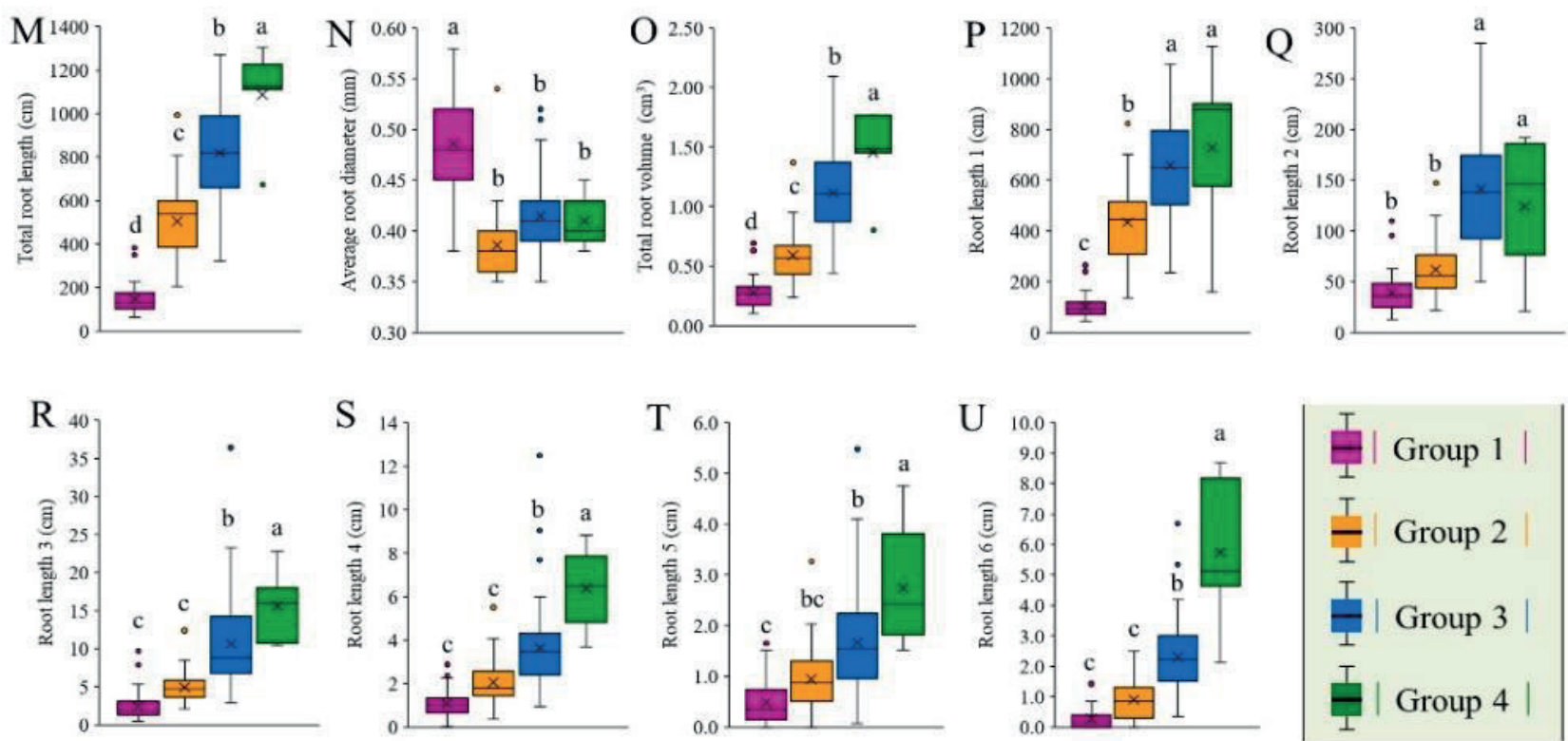

Figure 3. Emergence vigor, shoot and root traits in Passiflora edulis plants subjected to treatments with different substrates evaluated at 60 days after treatment and emergence speed index (ESI, evaluated during the emergence period). A) principal component analysis of the emergence vigor, shoot and root variables; B) dendrogram referring to the clusters according to the emergence vigor, shoot and root variables. The arrows represent the direction of the trait and the gradient colors represent the contribution of each trait to the components, from the blue gradient (low contribution) to red (high). Lowercase letters compare the means between groups by Tukey's test $(p \leq 0.05)$. AET: average emergence time; Chl: total chlorophyll content; E: emergence; ESI: emergence speed index; PH: plant height; NL: number of leaves; LA: leaf area; SDW: shoot dry weight. ARD: average root diameter; RDW: root dry weight; TRL: total root length; RV: total root volume; root length as a function of root diameter classes RL1: 0.0 to $\leq 0.5 \mathrm{~mm}$; RL2: $>0.5 \leq 1.0$ $\mathrm{mm}$; RL3: > $1.0 \leq 1.5 \mathrm{~mm}$; RL4: > $1.5 \leq 2.0 \mathrm{~mm}$; RL5: > $2.0 \leq 2.5 \mathrm{~mm}$ and RL6: $>2.5 \mathrm{~mm}$ diameter. G1-1: SCcNPK3:2 = soil + coarse coal + NPK at the 3:2 ratio; G1-2: SFcNPK2:3 = soil + fine coal + NPK (2:3); G1-3: SCcNPK2:3 = soil + coarse coal + NPK (2:3); G1-4: SFcEvNPK2:2:1 = soil + fine coal + enriched vermiculite + NPK (2:2:1); G1-5: SCcEvNPK2:2:1 = soil + coarse coal + enriched vermiculite + NPK (2:2:1); G1-6: SFcNPK2:3 = soil + fine coal + NPK (2:3); G2-1: SCcEv3:1:1 = soil + coarse coal + enriched vermiculite (3:1:1); G2-2: SFcEv3:1:1 = soil + fine coal + enriched vermiculite (3:1:1); G2-3: SFcEv2:2:1 = soil + fine coal + enriched vermiculite (2:2:1); G2-4:VFO1:1: Vivatto $^{\oplus}+$ fiber + Osmocote ${ }^{\circledR}$ (Control) (1:1); G3-1: CFcEh 2:2:1 = Control + fine coal + enriched hydrogel (2:2:1); G3-2: SCcEv2:2:1 = soil + coarse coal + enriched vermiculite (2:2:1); G3-3: SFcEh 2:2:1 = soil + fine coal + enriched hydrogel (2:2:1); G3-4: SCcEh3:1:1 = soil + coarse coal + enriched hydrogel (3:1:1); G3-5: SFcEh3:1:1 = soil + fine coal + enriched hydrogel (3:1:1); G4-1: SCcEh2:2:1 = soil + coarse coal + enriched hydrogel (2:2:1). 
A well developed root system is fundamental for the establishment of seedlings in the initial stage of development under field conditions, as it will promote the uptake of the water and nutrients needed for plant metabolism (Carmona, Anghinoni, Meurer, Holzschuh, \& Fraga, 2009). The root diameter classes represent the total length of roots in specific intervals of diameter. These variables are important to determine the exploration of the substrate by the roots, since younger and thinner roots are efficient in absorbing water and nutrients (Pierret, Moran, \& Doussan, 2005), possibly because the contact between the roots and the soil surface is maximized by the emission of root hairs, causing an increase in the root surface area and in its ability to absorb water and nutrients. Total root length was positively and strongly correlated with class R1 and negatively with average root diameter, revealing a logical trend, that the increase in root length is associated with the formation of thinner roots (Figure 2a).

When all emergence, shoot and root variables were analyzed, the same clustering trend was observed, with these variables being more favored with the use of hydrogel and poor performance occurring in the treatments using NPK in the formulation of the substrates (Figure $3 a)$. The variables of shoots and emergence vigor (Figure 3c-e) were less distinguished from each other than the root variables, as they showed greater dispersion within the groups of different substrates. This is corroborated by the box plots and cluster analysis (Figure 3 ).

When we analyze the groups formed by cluster analysis, a significant variation is observed for all traits, except for emergence percentage and total chlorophyll content, which were similar between the groups (Table 3). Overall, the root traits had a wide variability of response in relation to the different groups, making them more suitable to select the best substrates (Figure 3l-u). Some traits, such as emergence percentage and total chlorophyll content, were unable to discriminate any of the groups of substrates (Figure 3c, i). Group 1 included the substrates with lower costs, but average root diameter (Figure $3 n$ ) was also favored in group 1, where the highest average density was also observed, showing the effect of physical impediment on root development. In this group, average emergence time was also higher (Figure 3e). 


\section{Table 3}

Summary of analysis of variance for traits of emergence vigor, shoots and roots in Passiflora edulis plants subjected to treatments with different substrates evaluated at 60 days after treatment, and ESIemergence speed index (evaluated during the emergence period)

\begin{tabular}{|c|c|c|c|c|c|c|c|c|c|c|}
\hline SV & Emer. & ESI & AET & $\mathrm{PH}$ & NL & LA & $\mathrm{TCH}$ & SFW & SDW & RDW \\
\hline Group & $2.94^{\mathrm{ns}}$ & $13.06^{* *}$ & $10.53^{* *}$ & $58.14^{* *}$ & $45.04^{* *}$ & $61.86^{* *}$ & $1.14^{\mathrm{ns}}$ & $65.13^{* *}$ & $83.78^{* *}$ & $30.35^{* *}$ \\
\hline Residual & 461.86 & 0.005 & 18.8 & 4.26 & 0.81 & 1194.88 & 117.57 & 0.86 & 0.02 & 0.0019 \\
\hline CV (\%) & 26.52 & 33.39 & 25.28 & 25.07 & 18.31 & 36.28 & 25.83 & 35.3 & 30.88 & 38.94 \\
\hline & $\%$ & & days & $\mathrm{cm}$ & & $\mathrm{cm}^{2}$ & $\mu \mathrm{mg}^{-1}$ & \multicolumn{3}{|r|}{$\ldots \ldots \ldots . .}$. \\
\hline Mean & 81.04 & 33.39 & 17.15 & 8.22 & 4.93 & 95.28 & 41.97 & 2.55 & 0.49 & 0.11 \\
\hline SV & TRL & ARD & RV & RL1 & RL2 & RL3 & RL4 & RL5 & RL6 & \\
\hline Group & $126.83^{* *}$ & $50.30^{* *}$ & $93.14^{* *}$ & $99.68^{* *}$ & $53.77^{* *}$ & $40.79^{* *}$ & $82.10^{* *}$ & $27.08^{* *}$ & $72.3^{* *}$ & \\
\hline Residual & 33598.7 & 0.0014 & 0.07 & 272446 & 1847.5 & 17.84 & 2.05 & 0.60 & 0.95 & \\
\hline CV (\%) & 33.91 & 9.00 & 37.4 & 38.18 & 48.23 & 60.11 & 56.53 & 67.17 & 67.56 & \\
\hline & $\mathrm{cm}$ & $\mathrm{mm}$ & $\mathrm{cm}^{3}$ & \multicolumn{7}{|c|}{ 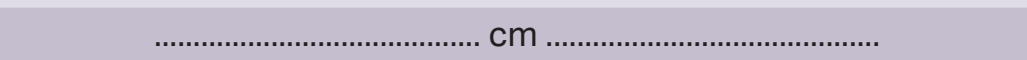 } \\
\hline Mean & 540.5 & 0.43 & 0.73 & 432.3 & 89.12 & 6.8 & 2.53 & 1.15 & 1.44 & \\
\hline
\end{tabular}

SV: source of variation; CV: coefficient of variation; ns: not significant, ${ }^{* *}$ : significant at $1 \%$ by the F test. Emer: emergence (\%); ESI: emergence speed index; AET: average emergence time; PH: plant height (cm); NL: number of leaves; LA: leaf area (cm2); TCH: total chlorophyll content $\left(\mu \mathrm{m} \mathrm{g}^{-1}\right)$; SFW: shoot fresh weight (g); SDW: shoot dry weight (g); RDW: root dry weight (g); TRL: total root length (cm); ARD: average root diameter (mm); TRV: total root volume ( $\left.\mathrm{cm}^{3}\right)$; Root length as a function of root diameter classes RL1: 0.0 to $\leq 0.5 \mathrm{~mm}$; RL2: > $0.5 \leq 1.0 \mathrm{~mm}$; RL3: > $1.0 \leq 1.5 \mathrm{~mm}$; RL4: > $1.5 \leq 2.0 \mathrm{~mm}$; RL5: $>2.0 \leq 2.5 \mathrm{~mm}$ and RL6: $>2.5 \mathrm{~mm}$ diameter.

\section{Conclusions}

The use of soil and fine and coarse coal reduced the costs of the substrates, but did not produce favorable results for the growth and development of P. edulis.

The substrate consisting of soil + coarse coal + enriched hydrogel $(2: 2: 1)$ was considered the best as it reduced costs by $23.72 \%$ in comparison to control treatment.

\section{Acknowledgments}

The authors thank the Bahia State Research Support Foundation (FAPESB) for the financial support and for the undergraduate research fellowship granted to the first and second authors, and the National Council for Scientific and Technological Development (CNPq) for the postdoctoral fellowship granted to the second author (L.K.S.L PDJ 152109/2019-6) and for the research project (process no. 421033/2018-5) and research productivity fellowship (O.N.J. PQ312774/2018-4) given to the fourth author. Finally, Embrapa Cassava and Fruits provided financial resources and support in all stages of the research project (MP 22.16.04.007.00.00).

\section{References}

Alencar, R. D., Leite, G. A., Mendonça, V., Lima, F. V. de, Pereira, G. A., \& Farias, W. C. (2016). Adubação potássica na produção e qualidade pós-colheita de goiaba 'Paluma' 
no semiárido potiguar. Comunicata Scientiae, 7(1), 139-148. doi: 10.14295/ cs.v7i1.1332

Almeida, M. O., Cruz, M. C. M., Castro, G. D. M., \& Fagundes, M. C. P. (2014). Crescimento e absorção de nutrientes por mudas de maracujazeiro-amarelo em substratos orgânico e comercial e adubação nitrogenada. Revista Brasileira Ciências Agrárias, 9(2), 180-185. doi: 10.5039/ agraria.v9i2a3593

Aular, J., \& Natale, W. (2013). Nutrição mineral e qualidade do fruto de algumas frutíferas tropicais: goiabeira, mangueira, bananeira e mamoeiro. Revista Brasileira de Fruticultura, 35(4), 1214-1231. doi: 10.1590/S0100-29452013000400033

Bomtempo, L. L., Costa, A. M., Lima, H., Engeseth, N., \& Gloria, M. B. A. (2016). Bioactive amines in Passiflora are affected by species and fruit development. Food Research International, 89(1), 733-738. doi: 10.1016/j.foodres.2016.09.028

Caldeira, M. V. W., Peroni, L., Gomes, D. R., Delarmina, W. M., \& Trazzi, P. A. (2012). Diferentes proporções de biossólido na composiçãodesubstratosparaaprodução de mudas de timbó (Ateleia glazioveana Baill). Scientia Forestalis, 40(93), 15-22. doi: 10.32404/rean.v3i4.1240 Retrieved from https://periodicosonline.uems.br/ index.php/agrineo/article/view/1240/0

Carmona, F. D., Anghinoni, I., Meurer, E. J., Holzschuh, M. J., \& Fraga, T. I. (2009). Estabelecimento do arroz irrigado e absorção de cátions em função do manejo da adubação potássica e do nível de salinidade no solo. Revista Brasileira de Ciência do Solo, 33(2), 371-383. doi: 10.1590/S0100-06832009000200015
Comas, L. H., Becker, S. R., Cruz, V. M. V., Byrne, P. F., \& Dierig, D. A. (2013). Root traits contributing to plant productivity under drought. Frontiers in Plant Science, 4(5), 442-470. doi: 10.3389/fpls.2013.00442

Faleiro, F. G., Junqueira, N. T. V., Junghans, T. G., Jesus, O. N., Miranda, D., \& Otoni, W. C. (2019). Advances in passion fruit (Passiflora spp.) propagation. Revista Brasileira de Fruticultura, 41(2), 1-17. doi: 10.1590/0100-29452019155

Farias, G. A., Costa, A. C., Costa, S. F., Farias, G. A., Pereira, P. H. F., \& Cabral, L. F., Jr. (2019). Produção de mudas de maracujazeiro amarelo em substratos contendo resíduos vegetais. Colloquium Agrariae, 15(1), 141-148. doi: 10.5747/ca.2019.v15. n1.a278

Felippe, D., Navroski, M. C., Aguiar, N. S., Pereira, M. O., Moraes, C., \& Amaral, M. (2020). Crescimento, sobrevivência e trocas gasosas de mudas de Eucalyptus dunnii Maiden submetidas a regimes de irrigação e aplicação de hidrogel. Revista Forestal Mesoamericana, 17(40), 11-20. doi: 10.18845/rfmk.v17i40.4902

Freitas, A. F., Souza, L. A. G., Cardoso, I. M., \& Paiva, H. N. (2014). Fino do carvão na produção de mudas de Dipterix odorata. Revista Brasileira de Agroecologia, 9(3), 31-40. Recuperado de http://revistas. aba-agroecologia.org.br/index.php/ rbagroecologia/article/view/15305

Freitas, J. P. X., Oliveira, E. J., Cruz, A. J., Neto, \& Santos, L. R. (2011). Avaliação de recursos genéticos de maracujazeiro-amarelo. Pesquisa Agropecuária Brasileira, 46(9), 1013-1020. doi: 10.1590/S0100-204X20 11000900007 
Instituto Brasileiro de Geografia e Estatística (2020). Levantamento da produção de maracujá no Brasil no ano de 219. Recuperado de https://sidra.ibge.gov.br/ tabela/5457/

Lima, I. M. O., Silva, J. S., Jr., Costa, E., Cardoso, E. D., Binotti, F. F. S. da, \& Jorge, M. H. A. (2016). Diferentes substratos e ambientes protegidos para o crescimento de mudas de maracujazeiro amarelo doce. Revista de Agricultura Neotropical, 3(4), 39-47. doi: 10.32404/rean.v3i4.1240

Lira, F. O., Souza, M. E., \& Maia, A. H. (2019). Crescimento de mudas de seringueira submetidas a diferentes doses de hidrogel e recipientes. Scientific Electronic Archives, 12(1), 40-45. doi: 10.32929/24 46-8355.2018v27n4p482-492

Ludwig, F., Fernandes, D. M., Guerrero, A. C., \& Bôas, R. L. V. (2014). Characteristics of substrates for nutrient absorption and production of gérbera. Horticultura Brasileira. 32(2), 184-189. doi: 10.1590/SO 102-05362014000200011

Maguire, J. D. (1962). Speed of germinationaid in selection and evaluation for seedling emergence and vigor. Crop Science, 2(1), 176-177. doi: 10.2135/ cropsci1962.0011183X000 200020033x

Mazurana, M., Fink, J. R., Silveira, V. H., Levien, R., Zulpo, L., \&Brezolin, D. (2013). Propriedades físicas do solo e crescimento de raízes de milho em um Argissolo Vermelho sob tráfego controlado de máquinas. Revista Brasileira de Ciência do Solo, 37(5), 11851195. doi: 10.1590/S0100-06832013000 500008
Meletti, L. M. M. (2011). Avanços na cultura do maracujá no Brasil. Revista Brasileira de Fruticultura, 33(SPE1), 83-91. doi: 10. 1590/S0100-29452011000500012

Miyake, R. T. M., Creste, J. E., Narita, N., \& Guerra, W. E. X. (2017). Substrato e adubação nitrogenada na produção de mudas de maracujazeiro amarelo em condições protegidas. Colloquium Agrariae, 13(1), 57-65. doi: 10.5747/ca.2017.v13.n1.a149

Nomura, M., Pereira, J. M., F., Costa, E. M., Pereira, L. S., \& Ventura, M. V. A. (2019). Avaliação de diferentes quantidades de hidrogel na produção de mudas de mamão papaya. Ipê Agronomic Journal, 3(1), 19-25. doi: 10.37951/2595-6906.2019v3i1.4320

Novotny, E. H., Maia, C. M. B. F., Carvalho, M. T. M., \& Madari, B. E. (2015). Biochar: pyrogenic carbon for agricultural use-a critical review. Revista Brasileira de Ciência do Solo, 39(2), 321-344. doi: 10.15 90/01000683rbcs20140818

Ohland, T., Lana, M. C., Frandoloso, J. F., Rampim, L., Bergmann, J. R., \& Cabreira, D. T. (2014). Influência da densidade do solo no desenvolvimento inicial do pinhãomanso cultivado em Latossolo Vermelho eutroférrico. Revista Ceres, 61(5), 622-630. doi: 10.1590/0034-737X201461050004

Pierret, A., Moran, J. C., \& Doussan, C. (2005). Conventional detection methodology is limiting our ability to understand the roles and functions of fineroots. New Phytologist, 166(3), 967-980. doi: 10.1111/j.1469-8137.2005.01389.x

R Development Core (2018). A Language and environment for statistical computing. Vienna, Austria: R Found Stat Comput Vienna. 
Rocha, C. W., Silva, M. A., Saraiva, T. S., \& Dayrell, D. M. (2017). Uso de diferentes substratos na produção de mudas de maracujazeiro amarelo. Revista Agro veterinária, Negócios e Tecnologias, 2(1), 38-51. Retrieved from http://fcc.edu.br/ pdf/20180525105832artigo2-38- 51.pdf

Silva, L. K. S., Costa, R. N., Santos, S. A., Silva, D. M. R., Santos, J. C. C., Pavão, J. M. S.,... Silva, J. V. (2019). Hidrogel melhora o crescimento inicial e qualidade de mudas de Enterolobium contortisiliquum. Scientific Electronic Archives. 12(3), 5361. doi: 10.36560/1232019729. Retrieved from http://sea.ufr.edu.br/index.php?journ al=SEA\&page $=$ article\&op=view\&path\%5 B\%5D=729\&path\%5B\%5D=pdf
Silva, W. L., Brito, C. F. B., Brito, A. S., Mesquita, N. L. S., \& Silva, Y. C. P. (2016). Desenvolvimento de maracujazeiro em recipientes e substratos a base de resíduo de vermiculita. Revista Agrotecnologia, 7(2), 53-60. doi: 10.12971/2179-5959/ agrotecnologia.V7n2p53-60

Zeraik, M. L., Yariwake, J. H., Wauters, J. N., Tits, M., \&Angenot, L. (2012). Analysis of passion fruit rinds (Passiflora edulis): isoorientin quantification by HPTLC and evaluation of antioxidant (radical scavenging) capacity. Química Nova, 35(3), 541-545. doi: 10. 1590/S0100-40422012000300019 
